\title{
2010 高圧ゴードン会議報告
}

2010 Gordon Research Conference on Research at High Pressure

\section{川村 春樹}

\section{Haruki KAWAMURA}

上記の会議が 6 月 27 日から 7 月 2 日までニュー ハンプシャー州プリマスの Holderness School で開 催されました。会議は 27 日の夕食後から始まり，7 月 1 日夜のコーネル大アシュクロフトの講演を最後 に翌日の朝食後散会となりました。会議はシングル セッションで行われ，九つのテーマに括られた 26 の講演と, 80 件のポスター発表がありました。参 加者は約 120 名, また日本からは米国在住の人も含 めて 10 名が参加しました。各テーマの題名を列挙 すると, 以下のようになります。

1) Structural prediction at extreme conditions

2) Young investigators in high pressure science

3) Ultra dense hydrogen

4) Novel dense structure and properties for material science

5) From QMC to disordered solids

6) Dynamic compression - from lasers to DACs

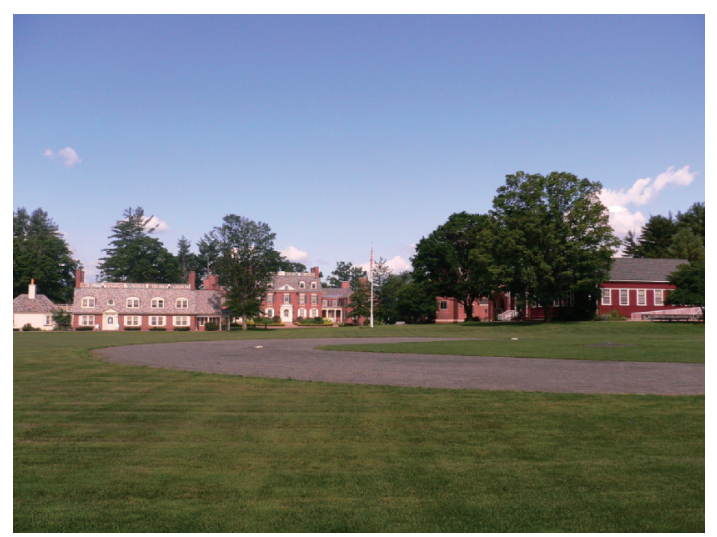

Fig. 1. The central part in south campus of Holderness School.
7) Chemistry and biology at high pressure

8) Geophysics and geochemistry at high pressure

9) High pressure advances and challenges

会議では最新の未発表のデータが歓迎され，記録 を残さないという方針ですので，個々の講演の内容 には踏み达反ませんが，テーマの題名で抢分かりの ように宇宙・地球から生物まで科学全般に亘る広い 分野の最新の話題が会議の沮上にのぼっていました。 タイム・スケジュールは午後の自由時間を挟んで, 午前中と夕食後 9 時半までが講演, それ以後がポス ターの時間になっていました。そのため, 日付を跨 いであちこちでビール片手の議論が続いていました。 プリマスという地名を聞くと, すぐにアメリカ合 衆国の建国神話に出てくる 1620 年, 102 名の清教 徒を乗せたメイフラワー号は長く苦しい航海の末, 無事新天地にたどり着いた，という港町を思い起こ す読者の方は多いのではないかと思います。しかし，

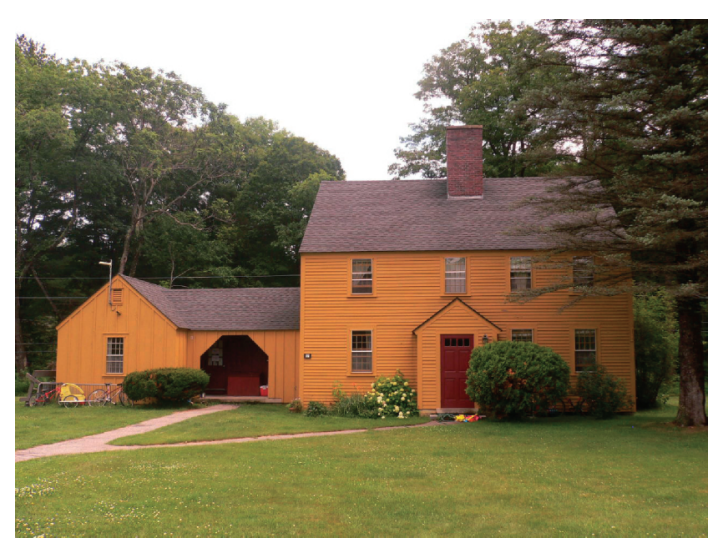

Fig. 2. A dormitory of Holderness School.

干678-1297 兵庫県赤穂郡上郡町光都 3-2-1 兵庫県立大学大学院 物質理学研究科

Graduate School of Material Science, University of Hyogo, 3-2-1 Koto, Kamigohri, Ako-gun, Hyogo 678-1297

Electronic address: kawamura@sci.u-hyogo.ac.jp 
このプリマスは建国神話に登場するプリマスからは 北へ $150 \mathrm{~km}$ ほどの内陸に在り, カナダとの国境が すぐ近くにあります。

Holderness School は丘陵地の林間に建てられた 1879 年創立の全寮制のハイスクールであり, 写真 のような小ぶりの寮が広い芝生のあちこちに点在し ています。19世紀のイギリスは斯くや，と思わせ るに足る雲囲気でした。子供の頃, 近くに住んでい たカリフォルニア帰りの日系 2 世の人が，東部の人 は発音まで違って近づき難かったとこぼしていまし たが，ニューイングランドには未だに古き格式ある イングランドが残されているのを知りました。

チェアーの好みでプログラム編成が大きく左右さ れるのかもしれませんが, 今回は広、領域の話題と いうこともあって, 年配の研究者が科学を楽しんで いる様子でした。しかし, 若手のための二件の受賞 講演も企画されて抢り, 大部分の参加者がこの寮に 宿泊し，三食を共に食堂で掑るため，その気になれ ば多くの知己が得られ, 若い研究者にはお奨めの会 議だと感じました。

最後にキャンパスの一隅の壁面で目に留まった ripple effect なる一文を記します。宗教臭がします が,「この教育効果にして, あのアメリカ人在りか」 との感がしました。
Powerful people are powerful influences.

If your life works, you influence your family.

If your family works, your family influences the community.

If your community works, your community influences the nation.

If your nation works, your nation influences the world.

If your world works, the ripple effect spreads throughout the cosmos.

Remember that your influence begins with you and ripples outward. So be sure that your influence is both potent and wholesome.

How do I know that this works?

All growth spreads outward from a fertile and potent nucleus.

You are a nucleus. 